\title{
SECURED FINANCING IN CANADA
}

\author{
DELLAS W. LEE*
}

The article sets forth a brief description of secured financing practices in Canada, with an indication of the respective roles taken by sales finance companies and chartered banks. Observations are made on the elements necessary for modern secured financing law and the extent to which these elements are found in the Ontario and Uniform Personal Property Security Acts. The barriers to the creation of a floating lien under current law are also explored, as are the philosophical implications arising from a law which validates a floating lien.

\section{Inventory and Retail Financing}

Each year in North America staggering amounts of capital are expended in the manufacture of "hard" or "durable" goods, prime examples of which are the automobile, housetrailer, washing machine, refrigerator, range, and machinery of all kinds. ${ }^{1} \mathrm{~A}$ vast amount of credit is extended by suppliers, finance companies, chartered banks and other lending institutions to finance the distribution of such goods. Much of this credit is in the form of sales on open account or loans obtained under a revolving credit account secured by nothing more than a personal or corporate guarantee. However, a highly significant portion of credit is secured by some type of chattel security device. For example, the outstanding balance of wholesale and retail secured credit extended by sales finance companies in Canada in August of 1969 was 2,455 million dollars. ${ }^{2}$ Although statistics do not distinguish between secured and unsecured credit granted by chartered banks, the outstanding, balance for general loans at the end of August, 1969, was 14,771 million dollars, ${ }^{3}$ a substantial portion of which was secured by chattel security devices. ${ }^{4}$

The financing of durable goods with secured credit takes place at two levels, variously known as (1) "wholesale," "inventory," "stock-in-trade," or "floor-plan" financing, and (2) "retail" or "consumer" financing. It has been observed" that the basic differences between inventory and retail financing are: consumer financing is based on a series of separate, single transactions, involving different debtor-purchasers, while inventory financing contemplates a continuous relationship between the financer and a single debtor (the wholesaler or retail dealer), under which virtually an infinite number of transactions may occur; (2) the retail purchaser generally makes a substantial down payment, but the wholesale purchaser frequently makes none at all; (3) the financer

- Professor, Faculty of Law, The University of Alberta.

1 In 1968, 4,805 million dollars were spent in the production of durable goods in Canada alone. Commercial Letter, Canadian Imperial Bank of Commerce, July-August, 1969 , at 10.

2 Bank of Canada Statistical Summary, August, 1969, at 636.

3 Id. at 586. The general loans figure consists inter alia of 8,503 million dollars lent to businesses, 4,170 million dollars in the form of personal loans, and 1,088 million dollars in loans to farmers. Id. Canada's gross national product for 1968 was 67,368 million dollars. Canadian Statistical Review, August, 1969, at 3.

4 One Edmonton bank reports that out of 1.471 non-agricultural personal loans made in August, 1969, 747, or about one-half of them, were secured by a chattel mortgage. Further, the bank estimated that over two-thirds of all loans to farmers are secured by a section 88 security interest. The section 88 security device also finds extensive use in securing business loans.

- Zlegel, The Legal Problems of Wholesale Financing of Durable Goods in Canada, (1963) 41 Can. B. Rev. 54, 55. 
derives a healthy profit by purchasing the retail paper, but virtually none from financing the inventory; ${ }^{\circ}$ and (4) the wholesaler acquires the collateral for resale, while the consumer-purchaser acquires it for use. $^{7}$

Several features of the two types of financing may be illustrated by examining the procedures followed in the distribution of automobiles and other machinery (first at the wholesale level). Although many facets of the illustration are just as applicable to the financing of airplanes, refrigerators, snowmobiles, and other serial-number products, ${ }^{8}$ some aspects, for example, the use of an approval number (rather than approval of a dollar amount only) and the allowance of "transit time" by manufacturers, may be too specific to be illustrative of procedures followed in the financing of less expensive items.

Automobiles and machine manufacturers traditionally operate on a cash basis. That is, the manufacturer will not ship the goods until it has cash in hand or is otherwise satisfactorily assured of receiving cash, although several of the automobile manufacturers will allow a certain amount of transit time during which payment need not be forthcoming. In order to obtain cash, in a typical case the dealer arranges a line of credit with a finance company-let us say, up to the amount of $\$ 300,000$. Prior to the new-car season a representative from the manufacturer takes orders from the dealer for a certain number of units and then contacts the finance company to obtain an approval number which will identify the credit to be used in ultimate payment for the cars. ${ }^{0}$ When the cars are ready for delivery, the manufacturer notifies the "pay office", i.e., a branch office of the customer finance company located near the manufacturer. The pay office then draws up a conditional sale agreement between the manufacturer and dealer on each unit, and an employee of the pay office signs the contract on behalf of the dealer pursuant to a power of attorney previously given the finance company by the dealer. The contract is then assigned to the finance company by the manufacturer and the finance company pays the wholesale price on behalf of the dealer. The conditional sale contracts, containing inter alia the approval number and information on the method of shipment, are then sent to the customer office of the finance company, with a copy going to the dealer. If, as is sometimes (or infrequently) the case, the financer deems himself insecure, he registers the conditional sale con-

- Canadian Economic Research Assoclates, Sales Finance Companies in Canada (1958) 8. For some data on the economics of wholesale and consumer financing in Canada see Hood, Financing of Economic Activity in Canada, (1958) 151-156.

7 For a penetrating study of the legal problems of inventory financing in Canada under pre-Act law (pre-Ontario Personal Property Security Act, 1967), see Zlegel, The Legal Problems of Wholesale Financing of Durable Goods In Canada, (1963) 41 Can. B. Rev. 54. For a description of the circumstances in other Commonwealth countries, Commonwealth and American Law (1965): Allan, Stock-in-Trade Financing, (1957) 2 U. Tasmania L. Rev. 382; Shere \& Allan, Financing Dealer's Stock-in-Trade, (1965) 2 U. Tasmania L. Rev. 382; Shere \& Allan, Financing Dealer's Stock-in-Trade, (1965) prior to the advent of the Uniform Commercial Code, see Cohen \& Gerber. The After-Acquired Property Clause, (1939) 87 U. Pa. L. Rev. 635; Kripke, Inventory Financing of Hard Goods, 1957) 74 Banking L.J. 1013; Skilton, Cars For Sale: Some Comments on the Wholesale Financing of Automobiles, (1957) Wis. L. Rev. 352.

8 Soft goods are generally financed by the suppliers on a 30-, 60-, or 90-day open account basis.

9 The approval number is a control technique commonly used by finance companies to ensure that the number of units shipped does not exceed the numbers ordered and/or that the line of credit is not exceeded. It is also a useful code by which the customerfinancing office and the pay-branch office are able to keep track of orders when they are ready for payment. shipment, etc. 
tracts. ${ }^{10}$ Since the dealer is frequently allowed a few days shipping time, before the finance company is required to make payment, for example, ten days in the case of a shipment from Brampton, Ontario, to Edmonton, Alberta, the "finance charge" (including interest) will not begin to run until the end of that time. At the end of the ten days the dealer is charged interest, currently at the rate of nine per cent, plus a service charge of seven to ten cents per vehicle per day. ${ }^{11}$

Thus the great majority of security by finance companies taken at the wholesale financing level is in the form of assigned conditional sale contracts covering the dealer's inventory. In the event of a dealer's bankruptcy, or an attachment or levy by a creditor of the dealer, the assignee of the contracts will take priority only if the contracts have been duly registered. In any event, a sale of the inventory in the ordinary course of business will cut off the financer's priority to the goods. ${ }^{12}$ This consequence is, of course, consistent with the financer's expectations, but it nevertheless makes inventory financing a risky form of business inasmuch as the goods may be disposed of in the ordinary course of business without remission of the proceeds to the lender pursuant to agreement. To protect himself against this risk the financer will generally obtain other security from the dealer, such as a corporate and personal guarantee. In addition the lender will usually make frequent stock checks. ${ }^{13}$ Thus in practice wholesale chattel paper is of little importance as a chattel security device, for example, as a convention for protecting the lender in the event of conflicting claims by third parties. ${ }^{14}$

In some fields of manufacturing the supplier may undertake to finance the sale of goods himself. But even here when chattel security is taken, it frequently ends up in the hands of a finance company before final payment has been made by the dealer. The obvious reason is that

10 Some finance companies would rather rely on frequent stock checks and up-to-date financial information than to incur the expense of registration:

Because of high registration costs and the volume of contracts, it is the practice of many sales finance companies in Canada not to register wholesale contracts unless the dealer is financially unsound or appears to be heading in that direction. About the only real protection one receives is against a Trustee in bankruptcy, and we prefer to rely on frequent stock checks and up-to-date financial information to guide us on whether or not we should register this type of contract. Most dealers on bankruptcy have absolutely nothing to distribute among the creditors and anything avallable is usually snapped up by the Crown and the Trustee for and anythis iees.

Letter to Professor D. W. Lee from G. E. Whitley, Secretary and Legal Counsel of Traders Groups Itd., Toronto, Ontario, November 14, 1968.

Although a line of credit with banks is a more common mode of financing used cars, occasionally finance companies will finance a dealer's used car inventory, in which case a chattel mortgage is taken as security. Registration of wholesale chattel mortgages appears to be more frequent than registration of wholesale conditional sale agreements.

11 In the days when money was less "tight" $5 \%$ interest as a finance charge was common, and in some instances no service charge was exacted whatever. A study made in 1958 indicates that the finance compantes examined were in fact losing money on wholesale financing, presumably expecting to recoup their losses through financing the retail sales. Canadian Economic Research Associates, supra. n. 6, at 8 . Occasionally a manufacturer will ship cars on a sale-or-return or "buy-back" basis. Under this arrangement title to the goods is in the dealer but he has the option of returning them to the manufacturer without obligation if he is unable to sell them, a practice which is followed generally only at the end of the model year to facilitate a practice which is followed generally only at the end of the model year to facilitate "clean-out". Under this practice the manufacturer will pay up to ninety-days"

12 Green Belt Holdings Ltd. v. Hollowaychuk, (1967) 60 W.W.R. 332 (Alta.); McRorie v. Seward, (1910) 13 West. L.R. 522, 3 Sask. L.R. 69 (C.A.); Dedrick v. Ashdown, (1888) 15 S.C.R. 227, 242 (Man.); National Mercantile v. Hampson, (1880) 5 Q.B.D. 177.

13 Field warehousing is virtually nonexistent in Canada.

14 The chattel paper has another important use, however. Typically the finance company will pledge the paper to another lender as security for loans which in turn will be used to finance further purchases by dealers. The parties intend that the pledgee, like the lending finance company, will be paid off from the proceeds derived from the sale of the goods in the ordinary course of business. 
few suppliers have sufficient capital to carry all the sales they can make and thus are forced to sell their paper in order to raise needed capital.

In Canada secured inventory financing and purchase of chattel paper at the wholesale level is engaged in almost exclusively by sales finance companies. In contrast with the American scene, Canadian banks are precluded from this form of inventory financing by the Bank Act, which appears to limit a bank's collateral under section 88 to a wholesaler's goods in the form of "products of agriculture, . . . the forest, . . . of the quarry and mine, the sea, lakes and rivers", to the "wares and merchandise manufactured or produced" by manufacturers, and to livestock of farmers and "products of the sea" of fishermen.15 However, banks appear to have a virtual monopoly on inventory financing in the areas in which no restrictions exist and on manufacturing financing. In these areas the devices most commonly used include an assignment of book debts and the section 88 security interest. ${ }^{16}$ If further security is desired and the magnitude of the loan justifies it, a bank may take a floating charge on the fixed assets as well as all other assets of the debtor. ${ }^{17}$ A certain amount of overlap of the security interests given other creditors may thereby result. Personal and corporate guarantees, assignments of mortgages, insurance moneys, etc., are also in common use by banks. ${ }^{18}$ Except for the section 88 security interest, any of these security devices are also available to nonchartered banks as lending institutions.

As indicated earlier, the inventory financer expects the loan to be paid off from the proceeds derived from sale of the cars in the normal course of the dealer's business. Some retail purchasers buy on a cash basis, but it is common knowledge that the vast majority finance their purchases by credit arrangements. For years the typical procedure has been for the dealer to take a down payment in the form of cash or a trade-in of the buyer's old vehicle, or both, and to secure the balance of the price, including a finance charge, with a retail conditional sale contract to which a promissory note is appended. The conditional sale contract and note are then assigned to a finance company, almost invariably the same company that finances the dealer's inventory. The dealer's profit comes from the difference between the wholesale and retail prices of the automobile plus a portion of the finance charge in the form of a commission or "kick-back", 10 more eup-

15 Canada Bank Act, R.S.A. 1955, c. 87, s. 88 (1) (a), (b), (f) \& (1) (1952) as amended. 1967. Although it appears that these terms are construed to refer to such goods in their natural state (see the definition in id. \$2) there seems to be no good policy reason why this functional limitation on the use of a section 88 security interest should exist.

16 Discussed in Jamieson, Chartered Banking in Canada (1953) 286, at 274.

17 For a brief discussion of the floating charge see Lee, International Secured Transactions, (1967) 17 Buffalo L. Rev. 85, 114-119.

18 Jamieson, supra n. 16, 293-302.

10 In some provinces the charges included in the term "finance charge" at the retall level represent only the interest rate charged on the unpaid balance of the cash price; i.e., there is generally no padding. However, this charge may be virtually any amount the purchaser will agree to, since it is not legally characterized as interest and therefore not subject to the interest or usury legislation. Regulation of interest incidentally falls under federal jurisdiction. The British North America Act. 1867, 30 Victoria, c. 3 s. 91, Appendices, R.S.C. (1952); The Interest Act. R.S.C. (1952) 156; Small Loans Act, R.S.C. (1952), c. 251. Some provinces have consumer-protection 156; Small Loans Act, R.S.C. (1952), c. 251. Some provinces have consumer-protection statutes of some relevance here. L.g., Alberta's Credit and Loan Agreements Act, S.A. (1967), c. 11, implements a disclosure policy but does not limit the amount that may be charged for the purchaser's privilege of paying the balance over a period of time. See Hughes, Conditional Sales and Consumer Protection, (1966) 2 Man. L.J. 15. The
Unconscionable Transactions Relief Acts, now enacted in all the provinces, in most 
hemistically known as "finance income." The amount of the dealer's commission will vary depending on the amount of the finance charge and the portion thereof the finance company will agree to let the dealer have. Thus everything collected over and above a certain percentage, for example, everything over eight per cent, may be allowed to be kept by the dealer. ${ }^{20}$ A portion of the commission, for example, five per cent, is customarily paid into a fund known as the "dealer's reserve" and is retained by the finance company to be applied against the dealer's "contingent liability" that may arise pursuant to the finance company's right of recourse against the dealer in the event of a purchaser's default under the contract. ${ }^{21}$ The finance company's profits are derived from the finance charge-the face value of the contract less the retail price and less the dealer's commission.

By virtue of recent amendments to the Bank Act lifting certain economic and legal barriers, since 1962 and more so since 1967 an increasingly greater number of consumer purchasers have obtained financing for their instalment purchases through secured loans from banks. ${ }^{22}$ Notwithstanding the loss of business by finance companies and loss of commissions by dealers that are obvious consequences of this new trend, finance companies report a steady growth in the volume of their outstanding consumer-sales credit.

In view of the fact that all chattel security devices are only variations on the same theme and therefore could be regulated by a single, comprehensive statute, it is obvious from the foregoing that a great amount of lost motion and confusion results from the existence of numerous statutes currently regulating chattel security devices within the provinces and a different set of laws for certain aspects of secured financing by chartered banks. Moreover, an examination of these laws, particularly those at the provincial level, reveals many inadequacies when modern manufacturer and inventory financing practices and needs are considered. Legal risks and costs to secured financers are accordingly increased. It was for the purpose of rectifying such problems that the Ontario Personal Property Security Act, 1967, was developed. Since this study is limited to an examination of the Ontario Act and related provincial law, and indirectly the Uniform Personal Property Security Act, there will be little occasion to make reference to banking legislation. However, it is believed that the banks and the public would benefit greatly from a federal statute that embodies the policies of the Ontario Act, assuming it is amended to correct its weaknesses, some

instances regulate only loans, and thus do not limit finance charges under instalment sales. See Waterman, In Defence of the Unconscionable Transactions Relief Act, (1963) 21 U.T. Fac. L. Rev. 117. See also Ziegel, The Legal Regulation of Consumer Credit in Canada, (1966) 31 Sask. B. Rev. 103.

20 The commission may be as little as $0.8 \%$ on new cars and as high as $3 \%$ on other kinds of stock.

21 Although recourse is not a right of the finance company, unless bargained for, nearly all the companies buy paper only on recourse. However, if the economlc strength of the dealer is great enough, he may be able to obtain a nonrecourse arrangement, particularly in those provinces which permit the conditional vendor to $g 0$ after the deficiency owing on the contract following default and repossession.

22 The major economic barrier was the limitation of interest chargeable by banks to a $6 \%$ maximum. This limitation was in fact frequently circumvented through the use of various charges classified by the banks as something other than interest, but use of various charges classified by the banks as something other than interest, but the legal restriction was no doubt an inhibition to full-scale participation in conwas the feeling among most banks that chattel mortgages could not be used except to secure an existing indebtedness. However, some banks hurdled this barrier merely by ensuring that the loan was made prior to the taking of the mortgage, even if only moments before. In any event these restrictions were removed in 1967. Can. Bank Act, S.C., (1967) 87 s8, 75, 91. 
of which will be pointed out in the course of this study. In fact banks would benefit from enactment of a Personal Property Security Act in the provinces since, as we have seen, banks make extensive use of several chattel security devices now governed by provincial legislation.

The basic elements of an adequate law to govern retail secured financing are few, and include mainly:

1. Minimal formal requisites for the creation of a security interest;

2. Provision for the perfection of the security interest; and

3. An equitable regulation of the rights of the parties before and after default, substantially preserving the principle of freedom of contract.

What is needed for inventory financing under ideal conditions, whether at the manufacturer or wholesale level, is a law that permits the lending institution to obtain a lien on raw materials, goods in process, or finished products, at any stage of production or distribution as security for loans to the manufacturer or dealer made to enable them to carry on business in times when they are unable or unwilling to use their own capital for this operation. Further, the law must permit the lien to shift from one form of collateral to another as it is transformed into, merged with, or replaced by new forms of collateral, including proceeds, at any stage between the manufacturing process and ultimate use or consumption, without the lender having to risk invalidation of his lien or being subjected to the burdensome and expensive requirements of registering a new security agreement for each new loan or change in collateral. The "ideal" floating lien law is not one that gives the secured party priority over third parties in all circumstances. Quite obviously the financer does not expect nor does he want a security interest which will prevail over a bona fide purchaser in the ordinary course of business. But the financer does expect priority over trade creditors, representatives of creditors such as a trustee in bankruptcy, subsequent secured creditors, and purchasers out of the ordinary course of business, at least as to tangible collateral of a non-negotiable character. To achieve these goals at minimum cost and inconvenience to both lender and borrower, having due regard for the rights of third parties, the chattel security law must contain the following attributes in addition to those required for a retail financing law:

4. Validation of after-acquired property and future advance clauses; ${ }^{28}$

5. Validation of a clause permitting the debtor to "deal with" or exercise dominion over proceeds derived from the disposition of the collateral without the legal obligation to account to the secured party;

6. Validation of a continuously perfected security interest in collateral as it is transformed by the manufacturing process or as it is replaced by proceeds upon sale or other disposition by a manufacturer, wholesaler, or retailer;

7. Provisions for a generalized notice filing system (advance registration-a mode of perfection); and

8. A systematic structure of priorities.

The Ontario Personal Property Security Act, 1967, contains all of these

23 Such clauses may permit a "cross-over" security whereby present and after-acquired property becomes security for present and future advances. 
elements except for a completely generalized notice filing system. Although notice filing is permitted to a limited extent, ${ }^{24}$ the floating lien available under the Act is not as flexible in some respects as the one contemplated by Article 9. The policies underlying the restrictions imposed in the Act are rather difficult to understand, and it is ironical that so much effort should be expended to develop a chattel security law having the attributes necessary for a truly functional floating lien only to restrict its implementation by unduly limiting the notice filing principle. The anomaly is all the more puzzling in light of the fact that the floating lien has for years received sanction in concept and to some extent in practice at both the provincial and federal levels.

The notice filing ${ }^{25}$ and description requirements ${ }^{26}$ have been dealt with elsewhere. Continuous perfection ${ }^{2 \pi}$ and the various priority rules ${ }^{28}$ must be treated at another time. The after-acquired property clause and the debtor's right to deal with the proceeds without invalidating the security interest are considered here, along with some policy questions relative to the validation of chattel security agreements and the floating lien.

\section{Should The Floating Lien Be Validated?}

Elemental to a consideration of the floating lien is the policy question of whether a floating lien should be validated at all or, even more fundamental, whether a creditor ought to be permitted a nonpossessory security interest under any circumstances. :

Although recognition of a nonpossessory security interest in chattels is a necessary condition to the development of an effective floating lien, common law notions of fraud and equity tend to oppose the creation of a floating lien of the type required by inventory financers. Equity has long favored the pro rata treatment of creditors when the debtor's estate is inadequate to satisfy the claims of all, and the concept has been enshrined in the maxim: "equality is equity." Legislation regulating liquidation generally is premised on the principle that creditors are to be treated equally. ${ }^{30}$ Given the tendency of human nature to be sympathetic toward both the honest debtor who has gambled everything and lost and his unsecured creditors who helped to build up the debtor's business, and we have the real possibility that courts seem disposed to accept almost any defect in a secured creditor's arrangement with his debtor as grounds for invalidating his security interest. Such judicial hostility to secured creditors often overlooks the economic fact that trade creditors typically make a greater profit on the sale of

24 The most recent amendment to the Uniform Personal Property Security Act (\$47) eliminates all limitations on the classes of collateral for which notice filing is available, thereby instituting a completely generalized notice filing system.

25 Discussed in Lee, Perfection By Registration, (1969) 47 Can. Bar Rev. 420, 444.

26 Adverted to briefly in connection with the description requirements for registration, Id. 449 .

27 See O.P.P.S.A. section 27, 28, see O.P.P.S.A. sections 29, 30, 31, 32, 34, 35, 36, 37, 38. 28 See O.P.P.S.A. Section 27.

20 Maitland, Equity (1936) 259; Pomeroy, Equity Jurisprudence, (5th Ed.) 144.

30 See, e.g. the Bankruptcy Act, R.S.C. (1952) c. 14, as amended (1966-67) in chapters 25, 32, 1100 : "Subject to this Act. all claims proved in the bankruptcy shall be paid pari passu," Quebec law accepts this principle of equality: "The property of a debtor is the rateably unless there are amongst them legal causes of preference." The burden is rateably unless there are amongst them creditor to show that he is entitled to a "preference," and the law is construed on the creditor to show that he is entitled to a "preference," and the law is construed
strictly to prevent a claim from being given more liberal treatment than necessary. strictly to prevent a claim from being given more liberal treatment than necessary.
Daillaire v. Gauthier \& Scott, (1903) 24 Que. S.C. 495; Wells v. Newman, (1897) 2 Que. S.c. 216. 
goods or the performance of services than is normally available to secured creditors through interest rates and finance charges. ${ }^{31}$ The reason the secured lender is willing to settle for lower profit is that he assumes he is undertaking less risk than the unsecured creditors. Under these circumstances it is not unreasonable or inequitable to give a secured creditor priority over the unsecured creditors. The unsecured creditors are likewise free to bargain for security if they wish. ${ }^{32}$ Indeed, in a day of registration systems for security devices and easy access to credit information regarding a debtor's financial status, it is not unreasonable to assume that unsecured creditors contemplate the possibility of a debtor's financial failure and their subordination to secured claims, and consequently insure themselves against this possibility by charging higher prices and fees. In any event, secured credit like unsecured credit is recognized as essential to the economy of Canada. ${ }^{33}$ This is evidenced by the fact that chattel security devices are validated by numerous statutes.

The floating lien is an economic reality on a limited basis in Canada, but whether it should be given unrestricted validation is controversial. The crucial policy question is whether a security interest should be permitted to extend not only to collateral in its original form but also to any new or altered form or substitute that arises anywhere along the manufacturing, wholesale, or retail line. A floating lien is not necessarily limited to a single piece of property or even class of property but may blanket all of a debtor's personal property both present and future. The arguments against the floating lien are usually predicated on one of two hypotheses: (1) that validation of a floating lien will result in an over extension of its use so that none of the debtor's assets will be available to satisfy the demands of unsecured creditors, thereby tending to close the door to this source of credit; and (2) that allowing a debtor to encumber all the present and future property in return for a present loan will encourage an improvident debtor to put himself in financial bondage. ${ }^{34}$

In reply to the first objection it may be argued that in a free enterprise system the forces of supply and demand operate in the credit market as effectively as in the market of more tangible commodities. If this is true, these forces will tend to maintain the necessary balance between the extent of security taken under a floating lien and the value of the assets to which unsecured creditors may look, or in equity ought to be able to look, in the event of the debtor's financial failure. The major competing interests in inventory financing are the trade creditors who supply goods or services to the debtor on open account and the financer who makes cash or credit avalable with which the debtor may pay the trade creditors or meet other business needs. If a financer takes a blanket lien up to the forced-sale value of the collateral, thereby leaving no margin of security for the trade creditors,

31 Canadian Economic Research Assoclates, supra n. 6, passium; Zlegel, The Draft Ontario Personal Property Security Act, (1966) 44 Can. B. Rev. 104, 130.

32 This is not true of all unsecured creditors, however. Wage earners, public utilitles, and tort victims, for example, obviously may not bargain like banks.

33 For a similar proposition with respect to the United States see Kennedy, The Trustee Articles 2 and 9, (1960) 14 Rutgers L. Rev. 518. Code: Some Problems Suggested By

34 I. G. Gilmore, Security Interests In Personal Property (1965) 360. 
the trade creditors will be driven from the field, ${ }^{35}$ unless of course the secured creditors are willing to finance the entire operation of the debtor; an unlikely possibility," or unless the trade creditors in effect insure themselves against the risk of not being able to share in the debtor's assets in the event of insolvency by spreading the risk through higher prices to all customers. As suggested earlier, practice appears to support the view that trade creditors do, in effect, insure themselves against this risk. A similar threat to the availability of unsecured credit arises from the possibility that on a debtor's insolvency or bankruptcy there will be virtually no assets in which the trade creditors may share. Nevertheless this real possibility has led to no shortage of trade creditors. $^{3 i}$ By the same token there appears to be no shortage of secured creditors either.

With respect to the possibility that an improvident debtor may place himself in financial bondage under the floating lien, the draftsmen of Article 9 took the position that the floating lien was already legally available and being employed in the states by one means or another under pre-Code law, thereby side-stepping the moral question. ${ }^{38}$ Canada is in a similar situation. Through legal and equitable liens of one sort or another it is possible to encumber all of a debtor's collateral under provincial law, ${ }^{39}$ and banks have been able to acquire a floating lien for a number of years under federal law..$^{40}$ The repugnance of debt peonage was, however, taken into consideration in provisions of Article 9, and thus the Act, which does much to eliminate the undesirable elements of a totally unrestricted floating lien."1 A striking illustration of the limitations placed on the potentially monopolistic use of the floating lien is found in section 34 which gives a purchase-money security interest in the same collateral priority over an earlier security interest under certain conditions. For example, suppose that a debtor has given a blanket lien on all his present and future property and later gets the opportunity to purchase a car load of umbrellas at an extremely low price if he can raise the money. Suppose further that the financer is unwilling to extend more credit for this transaction. Under the Act, can the debtor finance this purchase through another source and give a valid security interest on the newly acquired collateral as security and assure the financer priority? The answer is yes, providing the conditions of section 34 are met. ${ }^{42}$ Thus the adverse attributes of the floating

85 Le Dain. Security Upon Moveable Property In The Province of Quebec, (1956) 2 MeGill L.J. 77.

36 Ziegel, supra n. 31, 130.

37 This inference may be drawn from the statistics compiled in MacGuigan. Cases and Materials on Creditors Rights (1967) 460-62.

38 U.C.C. \$ 9-204 Official Comment 3.

39 Infra., text following note 42; Ziegel, supra n. 31, 130.

40 Infra., text following note 59.

41 I. G. Glimore, supra n. $34,360$.

12 The relevant portion of section 34 provides:

(2) Subject to Section 30 and 31 , a purchase-money security interest in inventory or its proceeds has priority over any other security interest in the same collateral,

(a) if the purchase-money security interest was perfected at the time the debtor recelved possession of the collateral; and

(b) if any secured party, whose security interest was actually known to the holder of the purchase-money security interest or who, prior to the registration by the holder of the purchase-money security interest. had registered a financing statement covering the same items or type of inventory, had received notification of the purchase-money security interest before the debtor received possession of the collateral covered by the purchase-money security interest; and

(c) if such notification states that the person giving the notice had or expected to acquire a purchase-money security interest in inventory of the debtor, describing such inventory by item or type. 
lien sanctioned by the Act are drastically reduced in some circumstances where unrestricted application would tend to work inequitable results.

The Act's built-in restrictions on the blanket lien are not as numerous as those in Article 9, but Canadian law, taken as a whole, will permit the creation of a floating lien of approximately the same scope and intensity as that available under Article 9. For example, there is nothing in the Act which limits a secured party's claim to unidentifiable cash proceeds to those which have been received and deposited in the debtor's bank account within ten days of the institution of insolvency proceedings against the debtor, as does section 9-306(4) of Article 9. However the legal and equitable rules of tracing may restrict the secured party's rights in these circumstances more severely than does the article 9 rule. The Canadian Bankruptcy Act permits secured claims to be proved and satisfied out of the security, which would include proceeds that are "identifiable or traceable." 43 Nor has Canadian law viewed an antecedent debt as an undesirable form of consideration for a security interest in after-acquired property. However the special definition of "antecedent debt" in section 9-108 of Article 9 (omitted in the Act) places American chattel security law in a similar position on this point.

However, if experience should demonstrate that, notwithstanding the forces of the market place and the limitations contained in the Act itself, secured creditors make unreasonably broad use of the floating lien, further restrictions on unwarranted application may be required.

\section{Provincial Law and the Floating Lien:}

The point was made earlier that it is possible under provincial law to encumber all the present and future assets of a debtor through legal or equitable liens of one sort of another. But regardless of what chattel security device is used there are serious barriers to the creation of an "ideal" floating lien.

\section{A. The Chattel Mortgage:}

A "stock" or "floating" mortgage is sometimes thought of as effectuating a floating lien, and indeed, so far as collateral of a fungible or nearly fungible nature is concerned, it is possible through a carefully drafted description clause to obtain a lien over present and after-acquired property. But in several respects such an arrangement falls short of a floating, specific, legal lien of the type required for inventory financing. The most obvious drawback is that if the future goods are nonfungible, and particularly if they are of a serial-number type, it may be impossible to make a "sufficient and full description of the goods." In such a case the "floating mortgage" would be unavailable because the intolerably burdensome requirements of separate documents, affidavits, and registration would be required for each transaction. Another weak-

A "purchase-money security interest" is defined in section 1(s) as a security interest that is:

(i) taken or reserved by the seller of the collateral to secure payment of all or part of its price, or

(ii) taken by a person who gives value for the purpose of enabling the debtor to acquire rights in or the use of collateral, if such value is applied to acquire such rights;

40 Bankruptcy Act, R.S.C. (1952) c. 14 as amended in (1967) chapters 25, 32, 88 86, 95, $63(2)$ and (3), and see id. $863(3)(b)$. 
ness is that an after-acquired property clause gives a chattel mortgagee merely an equitable title or lien on future goods when they are acquired, ${ }^{44}$ and registration is not necessarily notice to third parties. ${ }^{45}$ Thus a bona fide purchaser ${ }^{46}$ or subsequent legal mortgagee without notice may prevail over the equitable title of the chattel mortgagee. ${ }^{47}$ The mortgagee's lien is nevertheless good against a process creditor $^{48}$ and probably a trustee in bankruptcy. To obtain a legal mortgage, or to fully perfect the equitable lien under these circumstances, it is necessary for the mortgagor to do some act to ratify or reaffirm the contracta novus actus interveniens-after the goods have been acquired ${ }^{40}$ or for the mortgagee to take possession of the goods pursuant to authority..$^{50}$ Another major inadequacy of the chattel mortgage laws is that no provision is made for notice filing. ${ }^{51}$

\section{B. The Conditional Sale:}

As an instrument of inventory financing the conditional sale agreement has all the deficiencies of a chattel mortgage. But an additional weakness, the incompatibility of an after-acquired property clause to a conditional sales contract, makes it impossible to create even a semblance of as floating lien. Surprisingly enough, however, the conditional sales contract is used more frequently than the chattel mortgage in inventory financing. Registration costs for individual filings would be astronomical if such requirements were not generally ignored at the wholesale level. ${ }^{52}$

\section{Assignments of Book Debts:}

Under statutes regulating the assignment of book debts, the inability to describe precisely future accounts receivable poses no problem so that a single registered document could theoretically suffice to sweep in an infinite number of accounts arising from future sales. But the assignment of future accounts receivable, like a chattel mortgage, gives the assignee only an equitable interest, ${ }^{, 3}$ and registration of the assignment does not constitute constructive notices to subsequent assignees. ${ }^{54}$ Moreover, to perfect an interest in future accounts against subsequent

14 A. E. Thomas, Ltd., v. Standard Bank, (1910) 1 O.W.N. 379; Fraser v. MacPherson, (1898) 34 N.B.R. 417; Coyne v. Lee, (1887) 14 A.R. 503; McAllister v. Forsyth, (1885) 12 S.C.R. 1; Holroyd v. Marshall, (1862) 10 H.L. Cas. 191. The mortgagor is said to hold the property "In trust" for the mortgagee immediately upon acquisition. For comparison of the American pre-Code position see Cohen and Gerber, The AfterAcquired Property Clause, (1939) 87 U. Pa. L. Rev. 635.

45 Discussed in Lee, supra n. 25, 427.

40 But if the goods are stock in trade and are fraudulently sold out of the ordinary course of business, the mortgagee may recover them even though the mortgage contains an implied license that the mortgagor may sell the goods in the normal course of trade. Dedrick v. Ashdown, (1883) 15 S.C.R. 227, 242; Walker v. Clay (1880) course of trade. Dedrick v. Ashdown, (1888) 15 S.C.R. 227, 242; Walker v. Cla
49 J.J.C.P. 560; National Mercantile Bank v. Hampson, (1880) 5 Q.B.D. 177.

17 Reporter Publishing Company Ltd. v. Manton Brothers Ltd., (1961) 35 W.W.R. 498, 507-58; Whynot v. McGinty, (1912) 7 D.L.R. (N.S.) 618; Imperial Brewers v. Gelin (1908) 18 Man. L.R. 283; Wallace v. Scott, (1907) 5 W.L.R. 341 (Man.): McAllister v. Forsyth, (1885) 12 S.C.R. 1; cf. Joseph v. Lyons, (1884) 15 W.Q.B.D. 280 (C.A.).

18 Coyne v. Lee, (1887) 14 A.R. 503 (where an execution creditor in existence at the time the debtor received the soods was not permitted to prevail over a prior mortgage containing an after-acquired property clause covering stock-in-trade); Holroyd gage containing an after-acquired property clause covering stock-in-trade); Holroyd

19 Lunn v. Thornton, (1845) 1 C.B. 379, 135 E.R. 587: Langton v. Higgins, (1859) 28 L.J. Ex. 252, 157 E.R. 896.

50 Hope v. Hayley, (1956) 25 L.J.Q.B. 155.

51 Discussed in Lee, supra $\mathrm{n} .25,433$.

52 Id. at n. 22 .

58 Tailby $v$. Official Receiver, (1888) 13 A.C. 523. But the property assigned must be sufficlently described to enable its Identification upon coming into existence. In re Paddle River Construction Ltd., (1961) 2 C.B.R. (N.S.) 277: 35 W.W.R. 605 (Alta.)

s4 Snyders, Ltd. v. Furniture Finance Corp., (1931) 66 O.L.R. 79; (1931) 1 D. L. R. 398 (C.A.). 
assignees the rule of Dearle v. Hall, ${ }^{55}$ which requires the assignee to give notice of the assignment, to the account debtor prior to the subsequent assignment, must be reckoned with-an obviously unworkable rule if the advantages of a floating lien are to be had.

\section{The Floating Charge:}

As indicated earlier, the Act validates a floating lien which is not only legal and specific in function and effect, but, as the name suggests, the lien hovers over the collateral as it comes in and goes out of the control and ownership of the debtor. In the case of collateral undergoing a manufacturing process, the lien remains suspended but fixed while physical changes of the collateral either transform its nature completely or results in its being affixed to the property. In contrast the floating charge is neither legal nor specific. The suggestion sometimes made that the floating charge found in Canada and England is a functional floating lien is a too generous and misleading assessment. While in concept the floating charge bears some resemblance to a floating lien, a comparison of the two reveals only a remote similarity. The most striking difference is that the floating charge has always been.conceived of as an instrument of long-term comporate financing under which bonds and debentures are secured and later sold or pledged by the corporation to raise capital or credit. Moreover, since the charge-holder's interest is recognized only in equity, and since virtually any third party may take priority over the charge-holder till the happening of certain events, the charge hardly deserves the appellation of "lien." party has a right to obtain a legal lien-the only type that really counts where certain classes of third parties have intervened. ${ }^{57}$ Thus, prior to to the operative events, or "crystalization" as it is more commonly known, which may occur any time during the normal course of the debtor's business, subsequent mortgagees, process creditors, garnishments creditors, as well as purchasers, may take free of the floating charge. ${ }^{.8}$ This is less protection to the secured party than is obtainable under a stock mortgage since, as pointed out earlier, the stock mortgagee's equitable interest, even in future property, is protected against process creditors and the trustee in bankruptcy. So far as proceeds are concerned, there would be nothing to prevent the parties from stipulating that the debtor must account and that the secured party shall have the right to police

55 (1828) 3 Russ. 1; 38 E.R. 475. Discussed in Lee, supra n. 25, 432.

50 The floating charge remains inchoate or "uncrystallized" until the secured party takes steps to enforce his security interest or unless the business ceases to be a going concern. A mere default or demand is not sufficient cause for the floating charge to attach. Governments Stock \& Other Securities Inv. Co. v. Manila Ry. Co., (1897) A.C. 81; Matter of Panama, New Zealand \& Aust. Royal Mail Co., (1870) L.R. 5 Ch. A.C. 81 ; 318 .

57 The comment has been made that a floating charge "is not a specific mortgage of the assets plus a licence to the mortgagor to dispose of them in the course of his business . " and does not become a specific mortgage until the charge-holder takes steps to enforce his security. Evans v. Rival Granite Quarries, Ltd. (1910) 2 K.B. 979, 999; and see Meen v. Realty Development Co., (1954) 1 D.L.R. 649, 653 (Ont. C.A.): Pennington, The Genesis of the Floating Charge,'(1960) 23 Modern L. Rev. 630, 644-46. Perhaps the closest American analogue to the suspended nature of the Anglo-Canadian floating charge is an interest in crops had by a real estate mortgagee under a mortgage containing a "rents, issues and profits" clause, discribed in G. Glimore, mortgage containing
supra n. 34, 865:

[T] ihe usual construction of a "rents, issues and profits" clause has been that it creates no interest (or no more than an "equitable" interest) until the real estate man has, after default, taken possession of the land or had a receiver appointed.

A corporation is of course free to create a specific as well as a floating charge.

68 Kare v. North West Packers, Ltd., 63 Man. 16, (1955) 2 D.L.R. 407, 14 W.W.R. (N.S.) 251; Evans v. Rival Granite Quarries, Ltd., (1910) 2 K.B. 979. 
the disposition of the collateral, but these provisions are quite foreign to the normal function of a floating charge. Moreover an attempt to create a floating charge over inventory would no doubt be construed as a chattel mortgage as to tangibles, so that perhaps the device is not even theoretically available for stock. A noncorporate floating charge on accounts receivable does appear to be theoretically available, but such a device suffers from most of the weaknesses encountered in the case of tanglibles. ${ }^{59}$

Despite the shortcomings of the floating charge as an inventory financing device, it does render a valuable service in the area in which it was developed-long-term corporate financing-as attested by its wide and continued use. ${ }^{.0}$

\section{Federal Law:}

The closest Canadian analogue to the floating lien permitted by Article 9 and now the Act-one which has generally been overlooked because of its undescriptive name and exclusive nature-is the section 88 security interest available to chartered banks under the Bank Act. At least since 1923 a bank has been able to perfect its security interest taken pursuant to section 88 by filing a notice of intention, a simple statement by the debtor indicating his intention to grant a security interest to the bank, ${ }^{61}$ similar to the financing statement of Article 9 and the notice of intention of the Act. ${ }^{62}$ Moreover, it would appear that the security interest obtained under section 88 is legal and specific in nature so that even as to future goods the security interest would be good against subsequent mortgagees and process creditors, although a bona fide purchaser in the ordinary course of business would no doubt take free and clear. However, even a section 88 interest has its weaknesses as an "ideal" floating lien. Filing alone does not give the bank priority over subsequent third parties; the security interest may not be taken, it appears, for future advances; the security interest will not shift to proceeds derived from disposition of the collateral; ${ }^{103}$ and the section 88 security interest is available only to banks.

Were it not for the proposition that competition even among financial institutions of various classes is a salutory element in a free society, Canada could no doubt continue to get along reasonably well without a Personal Property Security Act for a while. But if this situation should continue much longer, banks would not only retain their superior position with respect to industrial and agricultural financing but, as in the United States, would no doubt move into all areas of wholesale financing as well. This would follow from the need for an adequate provincial

50 For a discussion of two cases relative to a floating charge on accounts receivable, see infra text, notes 84 and 89.

60 For law review treatment of the floating charge see Carroll. The Floating Lien and The Preference Challenge: Some Guidance From The English Floating Charge, (1967) 8 The Prefence Challenge: Some Guidance From The English Floating Charge, (1967)

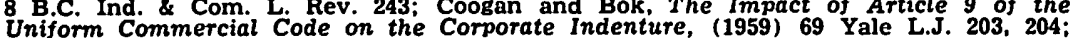
Uniform Commercial Code on the Corporate Indenture, (1959) 69 Yale L.J. 203, 204; The Genesis of the Floating Charge, (1960) 23 Modern L. Rev. 630 .

61 The Bank Act, R.S.C. (1952) c. 87, \$88(4), as amended 1967.

62 See the O.P.P.S.A. \$47, discussed Lee, supra n. 25, 444.

03 Zlegel, supra n. 5, 68. However, by a rather interesting process of reasoning a recent case reached the decision that a general assignment to a bank (pursuant to $s$. 88 of the Bank Act) of goods, and proceeds derived from their sale, gives the bank priority to such proceeds as against a trustee in bankruptcy notwithstanding the banks failure to register pursuant to the Assignment of Book Debts Act and in the face of failure to register pursuant to the Assignment of Book Debts Act and in the face of W. 63 of the Bankruptcy Act. Flintoft v. The
W.W. 65 (Man. C.A.), affd. (1964) S.C.R. 631. 
law to regulate secured financing, the ease with which the Bank Act could be adapted to permit the filling of this need, and the lucrative nature of the business.

\section{The After-Acquired Property Clause Under the Act (\$13(1)):}

Except for the limitations imposed on the effectiveness of the afteracquired property clause to be mentioned below, the after-acquired property clause is given broad validation by the Personal Property Security Act. It will be recalled that while Holroyd v. Marshall ${ }^{64}$ and Tailby v. Official Receiveris sanctioned a security interest in after-acquired property in the nineteenth century, the principles articulated in these cases and those that followed ${ }^{68}$ are of little comfort to the inventory financer since he may obtain only an equitable interest in the collateral thereunder, and some later act or conveyance is required to pass the legal title to the transferee. ${ }^{67}$ In the case of an assignment of book debts notice to the account debtor prior to the intervention of the interest of a subsequent assignee is required to perfect the assignment. ${ }^{08}$ Certain intervening third parties in addition to bona fide purchasers in the ordinary course of business may therefore prevail over the secured party. ${ }^{60}$

Section $13(1)$ of the Act states:

Except as provided in subsection 2 [re crops], a security agreement may cover after-acquired property and the young of animals after conception. ${ }^{70}$

Except for the specific reservation in subsection 2 with respect to security interests taken in crops, ${ }^{71}$ this terse statement categorically validates the after-acquired property clause. No distinctions are drawn on the basis of legal or equitable interests, nor as to the nature of the collateral, whether tangible or intangible. Accordingly a security interest in afteracquired property of all kinds has equal status with a security interest taken in property in which the debtor has rights when value is given. This follows from the fact that the security interest in after-acquired property attaches immediately on the debtor's acquisition of rights in the collateral, unless the agreement specifically postpones attachement. ${ }^{22}$ Assuming the secured party has already perfected his interest by registering the security agreement or notice of intention, no additional act of appropriation or new conveyance is required to consummate the interest of the secured party after the debtor acquires rights in the collateral, as is required under pre-Act law. But of course the security agreement must contain a description of the collateral that will ade-

64 (1862) 10 H.L. Cas. 191.

65 (1888) 13 A.C. 523.

66 Fraser v. Maciherson, (1898) 34 N.B.R. 417 (C.A.): Goulding v. Deeming, (1888) 15 O.R. 201 (C.A.); Lloyd v. European and North American Ry., (1878) 18 N.B.R. 194 (C.A.).

o7 Shatford v. Nelson, (1888) 20 N.S.R. 323 (C.A.); O'Kell v. Bell, (1883) 16 N.S.R. 419; Cummings v. Morgan, (1855) 12 U.C.Q.B. 565 (C.A.).

68 Dearle v. Hall, (1828) 3 Russ. 1, 38 E.R. 475

Bo Wallace v. Scott (1907) 5 West. L.R. 341, 16 Man. R. 594 (C.A.); Coyne v. Lee, (1887) 14 O.A.R. 503. With respect to subsequent assignees of book debts see Snyder, Ltd. v. Furniture Finance Corp., 66 O.L.R. 79. (1931) 1 D.L.R. 398 (C.A.).

70 The U.PP..S.A. recommends the amendment of $\$ 13(1)$ by deleting "and the young of animals after conception".

71 With respect to an after-acquired property interest in crops section 13 provides: (2) No security interest attaches under an after-acquired property clause in a

security agreement,
(a) to crops that become such more than one year after the security agreement has been executed, except that a security interest in crops that is given in conjunction with a lease, purchase or mortgage of land may, if so agreed, attach to crops to be grown on the land concerned during the term of such lease, purchase or mortgage.

72 For the right to delay attachment see Lee, supra n. 25 at 16 and 55. 
quately permit identification $(\$ 10)$. Thus if the steps for perfection have been taken ( $\$ 21)$, the relative position of third parties must be determined exclusively by the priority scheme of the Act itself rather than by resort to the rules of law or equity, unless the problem is not covered by the Act.

Section 13 (1) also makes a change in the law by viewing the young of animals as after-acquired property and by pin-pointing the time when a security interest in such progeny may attach. ${ }^{73}$

Finally, the rules of priority restrict the operation of an after-acquired property clause in the event a subsequent purchase-money security interest is taken by a secured party under certain conditions. ${ }^{74}$

\section{Dominion and Control-The Right to "Deal With" Proceeds:}

A requisite for the effective operation of an after-acquired property clause in wholesale financing is the legal validation of a clause giving the debtor dominion and control over, or freedom to "deal with," collateral and the proceeds derived from disposition of the collateral without loss of the secured party's security interest in either the original collateral or the proceeds. To ensure maximum flexibility of a security interest under a floating lien the law must permit the secured party to give the debtor authority to apply the proceeds against the debt, to purchase new collateral, to pay wages, or to use them in any other manner deemed necessary in the ordinary course of business. Such freedom may not always be desirable or necessary from the standpoint of the secured party, but it must be legally possible for the sake of flexibility in those instances where it is desirable. A law which restricts a debtor's dominion over the proceeds leads to the necessity of, a debtor's remitting the proceeds to the secured party for the sake of validating his right to them as against third parties only to require the secured party and debtor to go through the formalities of arranging another loan which will be validly secured under the law if the debtor should request another advance, as he normally will under the continuing relationship of an inventory financer. Rules which lead to repetitive, meaningless procedures only invite the parties to devise conventions for circumventing the requirements, as the American experience bears out.

Under American pre-Code law, an agreement which allowed the debtor to exercise unrestricted control over proceeds frequently resulted in invalidation of a creditor's security interest therein on the ground that the arrangement was potentially deceptive to third parties. To avoid this result various compromise arrangements were evolved, such as the adoption of contractual provisions requiring that the "proceeds of sales shall first be applied to the expenses of the business and the support of the mortgagor with the remainder to be allocated to the reduction of the debt." or that "a fixed percentage of the proceeds of the sale [be paid] to the mortgagee with the remainder to be used at the discretion of the mortgagor," or that the mortgagor use the proceeds

73 Wallace v. Scott, (1907) 5 West. L.R. 341, 16 Man. R. 594 (C.A.); Temple v. Nicholson, (1881) Cassels' S.C. Dig. 116, aff'g 20 N.B.R. 248; cf. Hirschfield v. Halifax, (1889) 22 N.S.R. 52 (C.A.). The U.P.P.S.A $\$ 12(3)(\mathrm{c})$ recommends amendment with respect to "the young of animals", by stating that a debtor has no rights in "the young of animals until they are conceived"

74 See O.P.P.S.A. $\$ 34(2)$ \& (3). 
to replenish the stock sold. ${ }^{75}$ The matter reached its peak in Benedict v. Ratner, ${ }^{76}$ where Mr. Justice Brandeis held that "reservation of dominion" was "inconsistent with effective disposition of title." The adequacy of symbolic or token control by the lender was rejected in that case, and the implication was that public notice via filing would not rebut the imputed fraud. This attitude induced financers to engage in elaborate "policing" procedures designed to ensure the appearance of circumstances that would not mislead third parties. ${ }^{77}$ Some courts invalidated security devices even where misleading circumstances did not exist merely because the secured party had failed to exercise control, thereby confusing legal invalidity with credit risk and interfering with business relations of no concern to anyone but the parties themselves. Article 9 in $\S 9-205$ rejects the principle enunciated in Benedict $v$. Ratner ${ }^{78}$ on the ground that third parties may adequately protect themselves by searching the notice-filing records. Policing of the collateral by the secured party will not necessarily come to an end, however, since this may be necessary as a matter of sound business practice. But policing for the purpose of demonstrating legal control is not required to perfect the security interest under the Code.

In Canada chattel security statutes traditionally have not provided for the shifting of a security interest in the original collateral to the proceeds derived from its disposition, and there appear to be no cases which have found the security interest to shift. Nevertheless a few wholesale financers do claim proceeds in the chattel security device. The questions therefore arise: (1) what is the effect of such a proceeds clause? (2) assuming it has some effect, what is the nature of an interest arising thereunder? and (3) of what effect is the existence or nonexistence of a requirement that the debtor make prompt accounting of the proceeds to the secured party?

If proceeds are claimed in the security agreement, the nature of a secured party's interest in the proceeds and whether he is entitled to them would appear to depend on the relationship found between the secured party and the debtor. If a principal-agent relationship is found, a very unlikely arrangement in modern financing practices, the financer would of course have title to the proceeds held by his agent, and the existence of a positive claim in the agreement would be unnecessary. ${ }^{70} \mathrm{By}$ the same token a stipulation requiring prompt accounting by the agent would be unnecessary to the secured party's right to proceeds, assuming the principal is not estopped from making his claim or barred by some other rule of equity or law. If a trust relationship is found, another unlikely possibility, the secured party would also prevail as to the proceeds, but in this instance it would seem that liberty in the debtor to deal with the proceeds may defeat the lender's claim as against third parties, since unrestricted control would be inconsistent with a trust

75 Cohen \& Gerber, Mortgages of Merchandise, (1939) 39 Col. L. Rev. 1338, 1346-47. 76268 U.S. 353, (1925).

77 In re Almond-Jones Co., 13 F. 2d 152 (D. Md. 1926), aff'd 16 F. $2 d 986$ (4th Cir. 1927). 78268 U.S. 353, (1925).

79 In two somewhat related cases a proceeds clause did exist: Banque Canadienne Nationale v. Lafaivre, (1951) Que. K.B. 83 (agency); In re David Allester, Limited, (1922) 2 Ch 211 (trust agency). In neither case did the finding of an agency relationship as that relationship is defined under common-law tests appear to be justified. 
relationship. ${ }^{80} \mathrm{~A}$ creditor-debtor or independent, relationship with the proceeds to be held in trust for the financer, the relationship most likely intended under current financing practices, ${ }^{81}$ would likewise seem to require a prompt accounting in order for the secured party to prevail against third parties, although there would appear to be no cases which have dealt directly with the question. In any event some of the largest finance companies feel that their claim to proceeds is so tenuous that they don't even bother to insert a proceeds clause in their wholesale agreements. ${ }^{82}$

The Ontario Act (\$27) eliminates the uncertainty in this area by permitting a security interest to shift from the original collateral to the proceeds. If the security interest in the original collateral was perfected at the time of dealing, the security interest in identifiable proceeds will continue perfected. ${ }^{83}$ The Act does not contain a section similar to section 9-205 of the Code in which it is expressly provided that "a security interest is not invalid or fraudulent against creditors by reason of liberty in the debtor . . . to use, commingle or dispose of proceeds, or by reason of the failure of the secured party to require the debtor to account for proceeds". However, in the absence of Canadian precedent similar to Benedict v. Ratner, ${ }^{84}$ it seems unlikely that its absence will cause any problems in light of the provision for a continuous security interest and the implicit acceptance of the constructive notice doctrine in the development of the priority rules.

It is interesting to note, however, that in the field of accounts receivable financing a somewhat related problem has arisen, namely the inclination to find a floating charge where the debtor is given authority to "deal with" the proceeds in the course of business. This tendency arose with the unfortunate decision in Great Lakes Petroleum Co. v. Border Cities Oil Ltd. ${ }^{85}$ In this case the debtor made an assignment of present and future advances and the assignment was duly registered as required by the Assignment of Book Debts Act. The assignment provided inter alia that the debtor could collect and "deal with" the ac-

80 Robin Hood Flour Mills, Ltd. v. Fuller Bakeries Ltd., (1963), 45 W.W.R. 449,42 D.L.R. (2d) 534, suggests otherwise, however. The case is discussed infra text note 88 . Compare Banque Canadienne Nationale v. Lefaivre, (1951) Que. K.B. 83; In re David Allester Limited, (1922) 2 Ch. 211; cf. In re Fred's Farm Industries Ltd., (1957) 36 C.B.R. 125 (Ont.). Only the Robin Hood case, and that case only by implication. dealt with the probable effect of a failure to make prompt accounting.

81 Ziegel, supra, n. 5, 107.

82 "[O]ur Company makes no express claim to proceeds in the case where goods are sold and bankruptcy occurs before the proceeds are remitted. I do not know of any Canadian law which would give us an enforecable claim to such proceeds, although some persons have argued that we would have such a claim. We simply claim as an unsecured creditor. I believe some of the subsidiaries of American finance companies do have a proceeds clause in the documents, but I have not heard of any of them trying to enforce it."

Letter to Professor D. W. Lee from G. E. Whitley, Secretary and Legal Counsel of Traders Group Limited, Nov., 1968.

"GMAC does not insert a clause in our whosesale conditional sale contract which would give or assign rights to proceeds taking preference over other unsecured creditors. More properly speaking, in the case of a bankrupt dealer or wholesaler where our collateral has been disposed of prior to bankruptcy and the amount encumbered to GMAC not settled, our position would become that of an unsecured creditor."

Letter to professor D. W. Lee from W. T. Quaile, Credit Manager Head Office, General Motors Acceptance Corporation of Canada, Limited, Nov., 1968. Compare the favored position of a chartered bank holding a s. 88 security interest under the favored position of a chartered bank holding a s. 88 security inter

Bank Act. Flintoff v. The Royal Bank of Canada, (1964) S.C.R
83 The relevant portion of section 27 of the U.P.P.S.A. provides:

(1) Subject to this Act, where collateral gives rise to proceeds the security interest therein,

(a) continues as to the collateral, unless the secured party expressly or impliedly authorized the dealing with the collateral which gave rise to the proceeds,

(b) extends to the proceeds.

84268 U.S. 353 (1925).

85 (1934) 2 D.L.R. 743. 
counts in the ordinary course of business until default or notice from the bank that he should cease doing so. Several years thereafter and before any default by the debtor or notice from the assignee, a judgment creditor of the assignor garnisheed H.B. Trucking Co., Ltd., a secondary debtor (debtor to the assignor), before the assignee bank had given notice of the assignment to the garnishee. ${ }^{86}$ The question was whether the garnishment creditor or the assignee bank was entitled to $\$ 343.00$ in the hands of the garnishee. The court held in favor of the judgment creditor on the ground that the provision giving the assignor dominion over the proceeds until default or notice from the bank converted the assignment into a floating charge which was dormant at the time of garnishment and thereafter until a default, notice, or other steps were taken to cause it to crystallize into a specific charge. The decision is open to criticism. As early as Tailby v. Official Receiver ${ }^{87}$ it was made clear that an assignment of future accounts receivable would cause an equitable interest to vest in the assignee upon their coming into existence providing they answered the description in the contract. There is nothing in that case or any other validating an assignment of future accounts receivable which requires the finding of a floating charge merely because the assignor has authority to deal with the proceeds. Granted such an arrangement contains one of the characteristics of a floating charge, there was nothing until the Great Lakes case to indicate that a power to deal with proceeds is necessarily inconsistent with a specific lien on accounts receivable. Since the court merely followed cases that dealt with the corporate floating charge of the type subject to the Corporation Securities Registration Act, ${ }^{88}$ without giving any policy reasons for its decision other than that the transaction looked like a floating charge, it is impossible to know whether the court might have been stirred by considerations similar to those underlying the decision in Benedict v. Ratner"8-that a "reservation of dominion inconsistent with the effective disposition of title" is fraudulent as to third parties-but it seems unlikely that it was.

The apparent seriousness of the Great Lakes decision for accounts receivable financing is minimized somewhat by a more recent Manitoba decision, Robin Hood Flour Mills Ltd. v. Fuller Bakeries Ltd. ${ }^{90}$ In this case the debtor, a bakery, assigned inter alia all its present and future book debts to the Bank of Nova Scotia as continuing collateral security to cover present and future indebtedness. The bank was to have power to designate the manner in which the accounts were to be collected and disposed of, and any proceeds received by the debtor were to be "held by the Customer in trust for the Bank". In practice the debtor collected the accounts receivable and used them in the course of its business to pay wages, supplier's accounts, etc. The assignment was duly registered, at which time the debtor owed the plaintiff some $\$ 6,000$. Later the creditor commenced action, obtained judgment, and garnished the government of Manitoba, which owed the debtor $\$ 2,900$.

86 Regarding the necessity of notice to perfect an assignment of a chose in action as against third parties, see Dearle v. Hall, (1828) 3 Russ. 1, 38 E.R. 475 .

87 (1888) 13 A.C. 523.

88 R.S.O. (1960) c. 70 .

89268 U.S. 353 (1925).

9042 W.W.R. 321, 40 D.L.R. (2d) 207 (Man. C.A.), reversed on a ground irrelevant to the discussion at hand, (1963) 45 W.W.R. 449, 42 D.L.R. (2d) 534 . 
The bank did not notify the government of Manitoba until after the garnishing orders had been duly served. The garnishment creditor claimed priority on the ground that the bank held only a floating charge that had not crystallized at the time of garnishment. Distinguishing the Great Lakes case the court gave judgment to the bank. It held that the assignment was absolute, notwithstanding that it was made as a "continuing collateral security". Accordingly, there was no interest remaining in the assignor to which the garnishment orders could attach. Moreover, since the debtor held the proceeds "in trust" for the assignee the assignment created a specific charge on the accounts receivable in favor of the assignee regardless of whether the funds were deposited in a special account to the credit of the bank or commingled in the debtor's own account. The facts did not make clear whether the assignor dealt with the accounts receivable with the permission of the assignee, but the opinion of the court appears to rest on the assumption that express or implied permission had been granted. ${ }^{91}$ In view of the fact that the assignment was made as a "continuing collateral security" for present and future indebtedness the finding of the court that the assignment was absolute is at least questionable. But even if this conclusion is accepted, it is difficult to see any practical difference so far as third parties are concerned between an assignment as security with permission to the assignor to use the collected funds until further notice as under the Great Lakes case, and an absolute assignment under which the assignor is to hold the funds in trust for the assignee but with free.dom to use them in the course of his business until directed otherwise. Nevertheless, the result of the Robin Hood Mills case is realistic since it in effect validates present practices under which assignments of this nature usually do, or easily may, provide that the debtor will hold the proceeds in trust for the assignee, thereby nullifying the potential impact of for the Great Lakes case.

Dominion problems of the nature discussed in the Great Lakes case become a thing of the past under the Act since floating charges not falling under regulation of the Corporation Securities Registration Act are subjected to the Personal Property Security Act $(\$ 2)$ as indicated earlier, ${ }^{92}$ and whether the debtor is required to hold the proceeds "in trust" or not becomes immaterial to the question of priority. Assuming the secured party has perfected his security interest by proper registration, it becomes specific and superior to the claims of process creditors, unless the security agreement contains an express clause postponing attachment of the security interest to some anterior time. ${ }^{93}$

\section{CONCLUSION}

Of the eight elements essential to an adequate inventory secured financing law, ${ }^{04}$ we have noted that four are either partly or totally unavailable under current provincial chattel security law. Moreover chattel

0142 W.W.R. 321, 338, 40 D.L.R. (2d) 207, particularly at 222-23. See also Evans Coleman and Evans Ltd. v. R. A. Nelson Construction Ltd. and City of North Vancouver
and Mercantile Bank of Canada, (1958) 27 W.W.R. 38, 16 D.L.R. (2d) 123 (B.C.A.A.). 9 and Mercantile Bank of Canada, (1958) 27 W.W.R. 38, 16 D.L.R. (2d) 123 (B.C.A.A.). 92 Under the U.P.P.S.A. S. 2, floating charges of all types, whether arising under a statute similar to a Corporation Securities Registration Act or otherwise (cf. The
Companies Act, R.S.A. 1955, c. 53, ss. 2, 99-104), are subject to the Act, with special provisions for their accommodation where necessary.

93 For a discussion of the right of the parties to suspend attachment of the security interest, see Lee, supra $n$. 25 at notes 16 \&5.

04 Text before and after note 23 , supra. 
security law throughout Canadian jurisdictions is in a most untidy state by virtue of the piece-meal manner in which it has come into existence. The inference to be drawn is clear: this area of the law deserves serious consideration by those interested in useful law reform. 